UDK 37:[172.16:321]

Georgios Pappas

ORCID iD 0000-0001-7139-9432

$\mathrm{PhD}$ (Philology),

Academic tutor for the subject "1SP12: Understanding the Language and Civilization: from Latin to Spanish" [Linguistics] Hellenic Open University (EAP), Dpt. of Hispanic Language and Civilization Studies

Greece,gspappasuoa@gmail.com

\title{
FOR THE EDUCATION OF THE COSMOPOLITAN. THE CASE OF TAGORE AND THE GLOBALIZED SELF
}

Summary. The phenomenon of globalization creates a variety of tensions and dilemmas. The present paper attempts to approximate this phenomenon by tracing the different trends arising from the corresponding descriptive, evaluative and regulatory judgments. In addition, the various philosophers' views on the dialogue on cosmopolitanism and patriotism are outlined, and Tagore's reflections and positions on cosmopolitanism and ecumenical education are highlighted, with emphasis on the development of critical thinking and constructive dialogue. The debate on globalization raises concerns and dilemmas in educational theory as well, with the consequent urgency of the need for rapid adaptation to the challenging environment.

The conclusion drawn from the presentation of the aforementioned positions is the need for the implementation of educational policies that will be based on education for empathy, solidarity and intercultural respect. Revisiting the commitment to culture within a universal horizon based on acceptance of diversity requires the existence of strategic planning that contains actions and choices that make it flexible and efficient.

Keywords: globalization, cosmopolitanism, patriotism, critical thinking, world education, educational and cross-cultural solidarity.

(C) Pappas G., 2020

https://doi.org/10.28925/2312-5829.2020.1.1

Introduction - Problematic of Work. In today's age, we are faced with a continuous evolution and the world is experiencing a continuous change where the only certainty that dominates is uncertainty (Handy, 1995). While it is true that peoples, cultures and economies were never unrelated or isolated, in the context of the aforementioned evolution, such connectivity and communication were radicalized and systematized, with the result 
that the phenomenon of globalization took on a new form due to its intensity and extent, of its characteristics (Zebylas, Petrou, Papastefanou, 2008). The term globalization describes the enlargement of the scale, the increase in intensity, the acceleration and deepening of the impact of trends and patterns of social interaction across the continents. Advances in communication, economics, technology and various other fields are shaping a new framework of dynamics that human contacts acquire. However, this new dynamic is not a sufficient and necessary condition for globalization to be seen as the forerunner of a harmonious global society or to be seen as a universal process of global integration in which there is ever greater convergence between cultures and cultures (Held \& Mc Grew, 2004).

In the new context of evolution and globalization created by the new evolving potential of human relations and contacts, the problematic of this work is included. In particular, it will be attempted, the current state of globalization to be traced in order the subtle manifestations and aspects of the phenomenon to be emerged. The purpose of the work is to critically review Nussbaum's views as presented in Pro-Homeland's book on cosmopolitanism and patriotism, to highlight Tagore's views on cosmopolitanism and a universal educational policy. An important pillar of this work's orientation, is the effort to bring cosmopolitan education into line with 21 st century educational policy.

The Aspects of the Globalization Phenomenon. The term globalization became widely known in the 1960s and early 1970s. This era of fast-growing economic interdependence of the Western states made it manifest the deficiencies of Orthodox thinking in the fields of politics, economics and culture since it provided for the strict separation of foreign and domestic affairs, local and global elements. In a world where there was greater interdependence, international developments had an immediate impact internally, and events within a state also affected the international scene. Following the collapse of state socialism and the worldwide prevalence of capitalism, public knowledge of globalization increased rapidly in the 1990s. Along with the revolution in the dissemination of the information that coincided with it, globalization seemed to confirm the view that the world was rapidly changing into a common social and economic space, at least for its most affluent inhabitants. However, the concept of globalization has been a source of widespread controversy both on the streets and at universities (Held \& McGrew, 2004). 
However, globalization, which is a complex state of shrinkage of space and time, is not only experienced but also debated, it becomes a theory, an ideology and a system of interpretation. It eventually becomes what is called globalization (Papastephanou, 2005). Despite the differences of opinion, globalization is perceived as a complex phenomenon and is associated with a modern tendency of systematic unification of the whole world on our planet. What makes globalization special and distinct is that it entails access and transcendence, that is, access to international markets, cultural practices and products, as well as transcending cultural, spatial and temporal boundaries with corresponding economic, political and cultural expansions (Zebulas, Petrou, Papastephanou, 2008).

There are three categories of positions in the debate on the phenomenon of globalization. For skeptics, the term globalization is not satisfactory. Since this term is not literally used as a synonym for the Ecumenical, then globalization is not far from being a synonym of Westernization or Americanization (Hirst, 1997). Skeptics study whether modern trends are comparable to those of the period in which many historians of economics have characterized the "belle époque" of international interdependence, that is, from 1890 to 1914 (Jones, 1995). Such analyzes, reveal that modern trends reflect a process of not globalization but internationalization as well as marginalization ${ }^{1}$ (Rugman, 2001). In addition, skeptics argue that the world today is shrinking economically, politically, and culturally as world empires have given way to nation states while the majority of the world's population has no access to the benefits of economic growth (Hoogvelt, 2001).

Proponents of globalization reject the position that it is synonymous with Americanization or Western imperialism. While they do not deny that its theory may well serve the interests of the West's powerful economic and social forces, they argue that globalization is an expression of deeper structural changes on the scale of modern social organization. These changes are reflected, inter alia, by the growth of multinational corporations, the growth of global financial markets, the spread of popular culture and the extent to which global environmental degradation has taken hold. The above point of view

\footnotetext{
${ }^{1}$ According to Rugman (2001), the process of internationalization implies the establishment of more and more links between separate national economies or societies, and regionalization means the geographical clustering of cross-border and social exchanges.
} 
places great emphasis on the spatial characteristics of globalization. In trying to differentiate global networks and systems from those operating on other scales, such as local or national, the followers of globalization mainly identify it with activities and relationships identified at the interregional or intercontinental level. Therefore, they can more accurately differentiate globalization from regionalization as well as from localization. The first term describes the network of relationships that are developed among geographically neighboring states, while the second one describes the grouping of social relations among states (Dicken, 1998). Central to the theory of the followers of globalization holds the idea that global change greatly transforms the organizational principles of life and the world order.

Regarding the third approach, the one of the critique of globalization, it is recognized as having a dual face, sometimes as progress and improvement of living conditions and sometimes as pure sovereignty (Zebyla, Petrou, Papastefanou, 2008). It is argued that the domination of the tendency to enhance locality, triggers a new social division and hierarchy (Bauman, 1998). The knowledge economy that abolishes old ways and relations of production, as well as the movement and sense of time of an elite without local ties, have the capacity to provide the rich with an unprecedented independence from the poor. The poor are thus removed from the privileged classes and bound to local conditions to the extent that mobility is no longer presented as a viable choice of life. At this point there is a convergence of views of Bauman and Habermas and the latter argues that the potential of disadvantaged groups to change their social status, has been nullified (Habermas, 1998). In conclusion, supporters of the critical view of globalization formulate a content-oriented proposal that focuses on diagnosing negative global consequences without, however, suggesting a leveling in its wording and general criticism.

While there are significant differences in the positions and views mentioned above regarding the multidimensional phenomenon of globalization, there are some common points that all sides would accept. Significant is the increase in economic interconnection within and among regions of the world, with diverse and disparate consequences for each community, for example. In addition, the spread of mutated foods, global terrorism, are increasingly transnational and cross-border problems, calling into question certain aspects of the national governments' traditional role, functions and institutions of responsibility. 
Tracing the basis of convergence of views can move to the next step, which is to cultivate the important values of social democracy - the rule of law, political equality, social justice, social solidarity and economic efficiency - and implement them in the new global form of economics and politics. In this way, within the framework of the impartial rule of law at the international level, there will be greater transparency, accountability and democracy in the reality of global governance.

Critical Approaches to Cosmopolitanism and Patriotism. The multidimensional nature of globalization creates the need to redefine the political context as citizens are called upon to face the reality of the treatment of others. This problematic revives interest in cosmopolitanism and highlights the dilemma of choosing between cosmopolitanism and patriotism. According to Papastephanou (2005), two trends have emerged from this revival. The first is about mobility, lack of roots, openness to different lifestyles and generally understanding of cosmopolitanism in a pragmatic way. The second involves the aforementioned strong legal and ethical dimensions. The second concept of cosmopolitanism is found in Nussbaum's discussion of Stoicism and in neo-Kantian and post-Kantian philosophical considerations.

Nussbaum, Professor of Philosophy at the University of Chicago, in her essay "Patriotism and Cosmopolitanism" highlights the cosmopolitan perspective that emphasizes the dedication to the human community on the one hand, and on the other hand, stresses the respect that everyone should attribute to the equal value of all members of the aforementioned community. In her book "Pro-Homeland Patriotism or Cosmopolitanism", opposing views on cosmopolitanism are presented through approaches that go against the ideal of universal citizenship in the name of sensitivities and relationships rooted in bonds among members of a group or in national tradition (Nussbaum, 1999). Man must be a citizen of the world, respecting the equal value of all members of this global community. Many of Nussbaum's interlocutors in their essays defend patriotism, localism, and nationalism in general, raising their concerns about the forthcoming globalization of a market that is in line with the imposition of Western values across the globe. In her selective essay, Nussbaum closes this public debate, responding to all of her interlocutors and reaffirming her 
commitment to the ecumenical community and her belief in universal values. The disagreement over cosmopolitanism is both theoretical and practical, with important implications for the contemporary debate on protectionism, human rights, immigration and what subjects should be taught in schools.

In her introductory note, Nussbaum quotes the characters in Tagore's novel "Home and the World" and identifies her views with those of hero Nickel, that the emphasis on patriotic pride is morally dangerous and subversive for some of the worthy purposes that patriotism serves, such as the goal of national unity as a commitment to worthy ethical ideals such as justice and equality. These goals would be better served by a more adequate ideology of man's position in the world, that of the cosmopolitan, of the man who believes in the global human community. Nationalism and ethnocentric attachment to particularity are not alien to each other, but relative - that by supporting nationalist sentiments ultimately overthrows the values that maintain the cohesion of a nation, by replacing essential universal values and international law with a graphic image. Nussbaum emphasizes learning about the history of other countries, their respective successes, problems (such as hunger and infection) and their consequences.

Nussbaum's central axis of the Kantian view of universality is fiction and education. The author argues in favor of reading literary texts because it is through the emotional approach of the reader to the fictional hero that the "imaginary leap" towards another's life is achieved, a prerequisite for recognizing difference.

However, Nussbaum's point of view raises a number of debates and objections from prominent intellectuals, sixteen of whom are included in Pro Homeland. It is characteristic that all its interlocutors oppose the ideal of universality, considering it either naive or dangerous and sometimes lacking in practical application. Instead of the Nussbaum's "cosmopolis", Appiah proposes a liberal democratic state in which citizens have no symbolic but literal value. He argues that we should defend not only the state but also the province, business, profession and family, as communities, as circles among the many circles that are narrower than the human horizon and which are spheres of moral interest. This view is supported by Barber, who considers universal citizenship a product of abolition and dissolution, while proposing an alternative to patriotism because it satisfies the need for 
a local identity without violating constitutional rules on democracy and freedom. Bok, thinks there is nothing wrong with encouraging children to fully explore their closest local existence to eventually reach beyond it. In addition, there is no necessary error in enduring pride, love, or identification with specific bonds, communities and cultures. This view is in agreement with the writer on encouraging children to fully explore their closest local existence. In this way, they will identify themselves and their close circles of influence in order to critique the training that promotes self-generated motivation. By gradually cultivating a critical attitude towards one's home, they will also be able to recognize the different other and to cultivate the appropriate attitudes to understand social phenomena that explain and adapt one's behavior to the various psychological and social phenomena. of their environment (Georgas, 1995). Falk, points out that the globalization of the market is not in line with the stoic moral imagination put forward by Nussbaum. He shares Nussbaum's vision on the one hand, but is disturbed by the fact that there is a marked encouragement in her text towards the polarization between national and cosmopolitan consciousness. Another objection is raised by Gutmann and Scarry, who believe that the achievement of world justice requires the establishment of legal democracies, where citizens have institutional means and constitutionally guaranteed rights. After all, the "protean ego", which Nussbaum envisions, is, according to Himmelfarb, a person without identity, just as the person who denies his nationality is a person without a nation. Pinsky, claims that instead of cultivating culture, as Nussbaum hopes, the trading space destroys cultures through homogenization. He also believes that Nussbaum's essay, expresses fear for the love of patriotism, but fails to imagine the counter love of cosmopolitanism. The cosmopolitan replaces it with the global, a more abstract and less historical concept. With this Nussbaum's mistake, it looks like confusing a historical language such as English with a construction like Esperanto. Many of Nussbaum's interlocutors argue that because of her origins, the author speaks from a position of power, provided that politically, economically, and socially strong American citizens have the option of attacking the weak or of " great-hearted" understanding the difference without losing their privilege in both cases. Glazer, goes a step further by 
emphasizing the inevitable connection of cosmopolitan devotion with the Western colonial cultural tradition, which, in turn, originates with the ideal of globalization.

\section{Tagore's Cosmopolitanism and His Views on an Ecumenical Education Policy.} Tagore tries to reconcile his identity and the context of the culture, history and society he belongs to, with the reality of other identities, cultures, people. His posts are an example of the compatibility of cosmopolitanism with patriotism. For him, cosmopolitanism implies an emotional and moral belief and an investment in humanity's interests (Nussbaum, 2000). One should always behave in a way that treats with equal respect the dignity of logic and moral choice in every human being. The attitude of the cosmopolitan is essentially valuable because it recognizes in humans the essential attributes that deserve respect and acceptance.

The emergence of cosmopolitanism from the basic proposition that humanity belongs to a single ethical community, then cosmopolitanism views individuals as identical entities with equal visions regardless of their particular nationality (Tan, 2004). Tagore does not see nationalism and cosmopolitanism as opposing concepts, but as interdependent. The vision of cosmopolitanism is based on global humanism Nussbaum, and thus, traces Tagore's cosmopolitanism which is a mixture of Bengali tradition and western cosmopolitanism (Ray, 2000). Tagore's position on transnationalism is a call for cooperation that is manifest in his cosmopolitan ideology. His political philosophy encompasses the potential for showing the positive interactions that can take place between nations based on dialogue and exchange (Bhattacharya, 2009).

Tagore's statements and practices regarding education are based on the assumption that education is not a profession but an art. The approach to education is realized through poetry. Intuition and experience, rather than scientific research, have been Tagore's pillars for educational reform (Aronson, 1962). Creation, productivity and imagination have pushed him to transform educational practice into an important process that will lead to the successful integration of the individual into society. The core of his educational ideals is determined by his belief in the harmony that must be achieved in the individual where all the opposing elements that make up the human personality are unified.

Critical thinking is especially important in a society where people differ in ethnicity, religion and social class. Consequently, a constructive dialogue can take place if new 
citizens first know how to engage in dialogue and participation. The aforementioned knowledge is achieved if young people learn how to think the reasons that push them to support a situation from a different one. Therefore, when politicians promote their positions through simplistic propaganda, young people through critical thinking will have the hope of maintaining their independence and thinking of alternatives (Nussbaum, 2006).

21st Century Cosmopolitan Education and Educational Policy. Globalization in education is linked to its role in global dialogue. If globalization is recognized as a contributing and active reality that brings individuals and groups into collaboration and communication, then the education that best serves it, will be one that can extensively revise its programs both at the level of geography and ecology of other nations knowledge, as well as the counterpart of knowledge of the traditions and cultures of other nations so that communication is based on understanding and familiarity (Nussbaum, 1999). In today's time, it is necessary to rethink our commitment to culture within a universal horizon and to reflect on the potential and importance of the coexistence of cultural and universal ideals for modern education.

In defining the concept of intercultural education we are referring not only to the encounter of cultures, but also to the encounter of one's personal culture with that of one's neighbor, who are by definition heterogeneous, even within a homogeneous ethnic group. Intercultural education means opposing through everyday pedagogical practice any form of discrimination, be it social, cultural, gender, linguistic or religious. In any stereotypical hierarchy of the different, modern education must adopt both cultural and universal ideals. The decision to reduce and eliminate interpersonal and intercultural differences by highlighting all the universal elements that bring us closer together, will effectively contribute to conflict management (Campbell, 2000).

As already mentioned, intercultural education is a special pedagogy aimed at more effectively managing cultural differences and preparing students for active participation in the knowledge society, in a pluralistic socio-cultural environment. It is a dynamic process of interaction and mutual recognition and cooperation between individuals from different ethnic groups. The main pedagogical principles that characterize intercultural education are: 
1) empathy, that is, to learn to understand others, to position ourselves and cultivate our sympathy for them, 2) education for solidarity, that is, the development of a collective consciousness that transcends tribal and state boundaries, 3) education for intercultural respect, which respects cultural diversity and opens itself to other cultures, 4) education against nationalist thinking, that is, the elimination of national stereotypes and prejudices and the call for dialogue and solidarity (Nikolaou, 2003). In any case, the main concern of intercultural education is to deal with the institutional changes that need to be made both at the curriculum level and at the level of the school culture in order to take into account the special conditions and needs of minority students with disabilities. The aim is to achieve equal school and social integration. From a psychological point of view, the teaching of the linguistic and cultural heritage of minority groups promotes the enhancement of their selfconcept and school performance and, consequently, equality of opportunity in education and society (Papanis, 2009).

In conclusion, in the newly shaped state of globalization, States' educational policies must shift from the ideology of crucible and integration, to multicultural education, a shift from the ideology of cultural imperfection or delay, to cultural difference.

Summary - Conclusions - Recommendations. Evolution in various fields such as communication, economics, technology, brought about by the phenomenon of globalization, gives new impetus to human relations and contacts. However, the new framework does not automatically mean harmony and unification. Three categories emerge in the dialogue taking place on this phenomenon. The first category includes positions that express concern that globalization is a new form of oppression, the second contains positions that look optimistically on the phenomenon, and the third category implies positions that on the one hand share the concerns of the first category, on the other hand, show a critical disposition for the double face of the phenomenon, sometimes as progress and sometimes as sovereignty.

In the dialogue between cosmopolitanism and patriotism, Nussbaum and other philosophers present their views and opinions. Nussbaum puts forward a cosmopolitan perspective that emphasizes the dedication to the community of the human race on the one hand and stresses the respect that everyone must show to the equal value of all members of For the education of the cosmopolitan. The case of Tagore and the globalized self 
that community. However, there are also opposing views that raise concerns about globalization as it imposes Western values around the globe. In addition, they defend patriotism and nationalism through their own perspective, giving priority to these elements. Nussbaum defends Tagore's positions, and their views converge on the critical thinking that must be cultivated in young people in order to exchange ideas with others in an atmosphere of mutual respect to resolve and settle any differences peacefully in a world where polarization is heightened by nationalist and religious conflicts (Nussbaum, 2006).

The facts of the new reality must be taken seriously into consideration by States, in order for them to implement those educational policies in which the diversity of each one will be treated in an equal manner within a single educational system that will highlight the interplay of cultures based on cultural and universal ideals. Therefore, the adoption of strategic planning with actions that make it flexible and adapted to the situation is imperative and should be carried out without delay to improve education and meet the challenges. The nature of the restrictions, the nature of the ethical dilemmas, the frequency with which they are presented and the ways in which they can be addressed may be the subject of further research and study.

\section{References}

Aronson, A. (1962). Tagore's educational ideals. International Review of Education, 7 (4), 385-393.

Bauman, Z. (1998). On Globalization: Or Globalization for Some, Localization for Some Others. Thesis Eleven, 54, 37-50.

Bhattacharya, 2009. Colonialism, Nationalism and Cosmopolitanism of Rabindranath

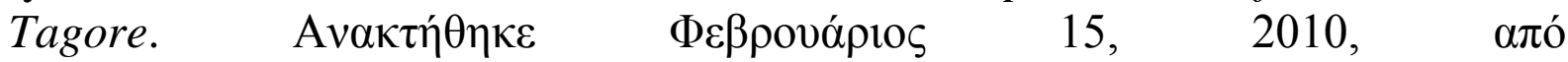
http://www.allacademic.com/one/www/research/index.php?cmd=www_search\& offset=0\&limit=5\&multi_search_search_mode=publication\&multi_search_publi cation_fulltext_mod=fulltext\&textfield_submit=true\&search_module=multi_sea rch\&search=Search\&search_field=title_idx\&fulltext_search=\%3Cb\%3EPostColonialism $\% 2 \mathrm{C}+$ Nationalism+and+Cosmopolitanism+of+Rabindranath+Tagor $\mathrm{e} \% 3 \mathrm{C} \% 2 \mathrm{Fb} \% 3 \mathrm{E} \& P H P S E S S I D=$ fbe750a64507a3b486d4e1503f768023

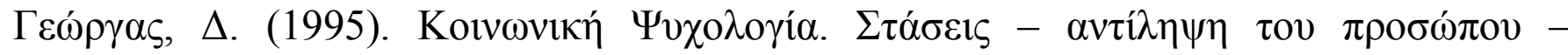

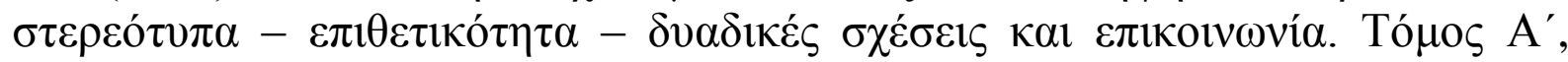

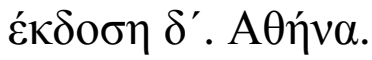


Campbell, A. (2000). Cultural identity as a social construct. Intercultural Education, 11 (1), 31-39.

Dicken, P. (1998). Global Shift. London: Paul Chapman.

Habermas, J. (1998). Learning by Disaster? A Diagnostic Look Back on the Short $20^{\text {th }}$ Century. Constellations, 5 (3), 307-320.

Handy, C. (1995). The Empty Raincoat; Making Sense of the Future. London: Arrow Business Books.

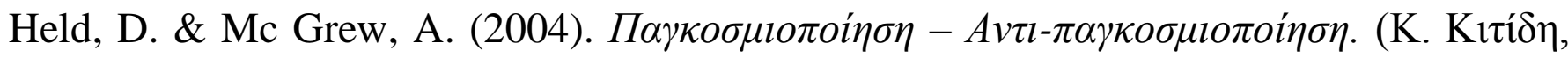

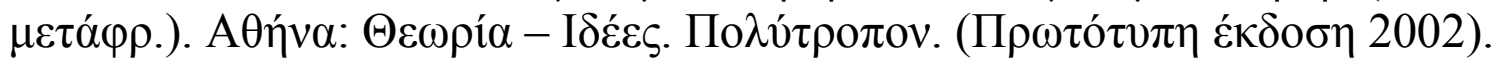

Hirst, P. (1997). The global economy. Myths and realities. International affairs, 73 (3).

Hoogvelt, A. (2001). Globalization and the Postcolonial World. Basingstoke: Palgrave.

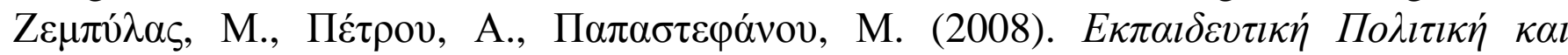

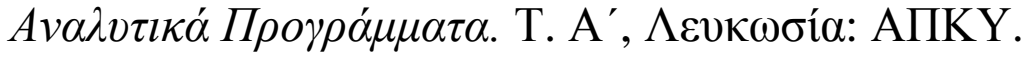

Jones, R.J.B. (1995). Globalization and Interdependence in the International Political Economy. London: Printer.

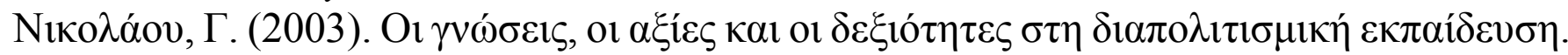

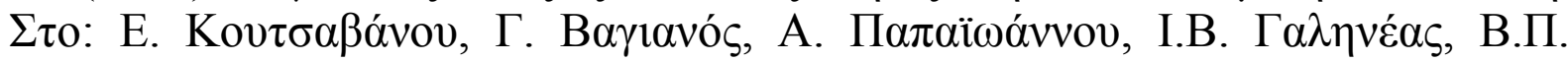

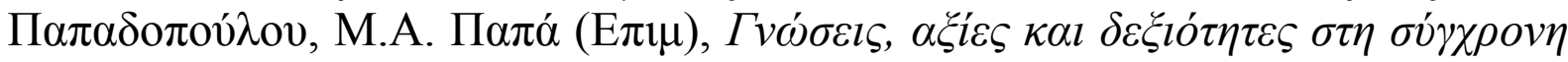

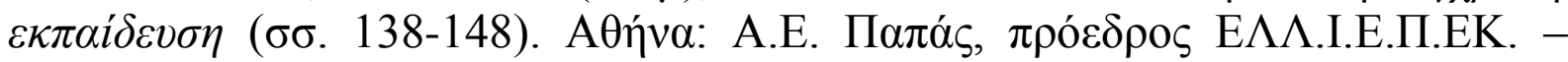

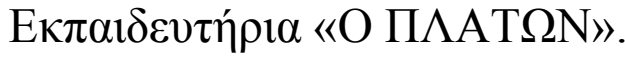

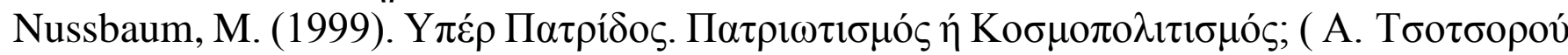

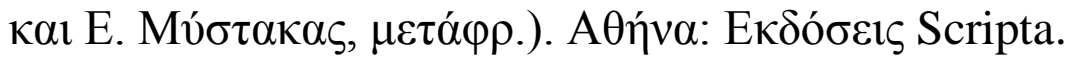

Nussbaum, M. (2000). Symposium on Cosmopolitanism. Duties of Justice, Duties of Material Aid: Cicero's Problematic Legacy. The Journal of Political Philosophy, 8 (2), 176-206.

Nussbaum, M. (2006). Educational and Democratic Citizenship: Capabilities and Quality Education. Journal of Human Development, 7 (3), 385-395.

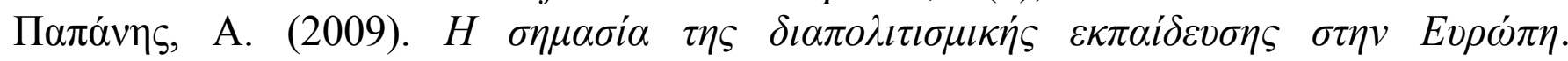

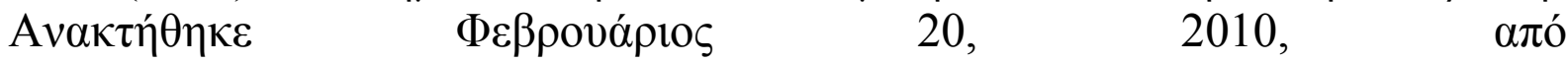
http://alexandrospapanis.blogspot.com/2009/11/blog-post.html

Papastephanou, M. (2005). Globalization, Globalism and Cosmopolitanism as an Educational Ideal. Educational Philosophy and Theory 37 (4), 533-551.

Ray, S. (2000). En - Gendering India - Woman and Nation in Colonial and Postcolonial Narratives. Durham and London: Duke University Press.

Rugman, A. (2001). The End of Globalization. New York: Random House.

Tan, K-C. (2004). Justice without Borders: Cosmopolitanism, Nationalism and Patriotism. UK: Cambridge University Press.

\section{ДО ПИТАННЯ ОСВІТИ В УМОВАХ КОСМОПОЛІТИЗМУ. Р. ТАГОР І ГЛОБАЛІЗОВАНЕ «Я»}

Георгіос Паппас, $\mathrm{PhD}$ з філологічних наук, тьютор кафедри романських мов та цивілізаційних досліджень, Грецький відкритий університет, Греція, gspappasuoa@ gmail.com 
Явище глобалізаиії призводить до різноманітних дискусій, створює напругу в суспільстві, викликає дилеми, протилежне бачення самого питання. У запропонованій статті подана спроба апроксимувати явище глобалізащії, простежене за різними сучасними тенденціями; результати спостережень та отримані показники викладені описовими, оцінними і регулюючими судженнями. Крім того, представлені різні філософські погляди в діалозі питань із космополітизму та патріотизму, на яких сфокусовані філософи та футурологи.

Порушені питання глобалізації у статті розглянуто разом з баченнями Р. Тагора і його позииї щодо космополітизму та всесвітньої освіти, де робиться акцент на розвитку критичного мислення і конструктивного діалогу. Дебати щцодо глобалізачії в освітньому просторі викликають побоювання та протиріччя, хоча й виникла невідкладна потреба в швидкій адаптаиії до соціального і культурологічного різноманіття навколишнього середовища.

Поява поняття міжкультурної освіти є наслідком процесів глобалізації. Автор статті зазначає, що міжкультурна освіта означає протистояння через повсякденну педагогічну практику в будь-якій формі дискримінаиії, будь то соиіальна, культурна, гендерна, мовна чи релігійна. Таким чином процес інтеграції є неможливим без створення динамічного прочесу взаємодії, взаємного визнання та співпрачі між людьми з різних етнічних груп. Необхідно переосмислити свою прихильність до культури в рамках універсального горизонту та задуматися над потениіалом та важливістю співіснування культурних та загальнолюдських ідеалів для сучасної освіти.

Оминання, невирімення вищезгаданих питань - цее невирімення потреби та невиконання освітньої політики, яка має бути трунтовною з позицій освіти співчуття, солідарності та міжкультурної поваги. У роботі проповідуються зобов'язання перед культурою та міжкультурною освітою в межах універсального горизонту.

Ключові слова: глобалізація, космополітизм, патріотизм, критичне мислення, всесвітня освіта, освітня та міжкультурна солідарність. 